\title{
Experience from fifteen years of Malagasy lychee export campaigns
}

\author{
Michel JAHIEL ${ }^{1,2 *}$, Christophe AndREAS ${ }^{1}$, Eric PenOt ${ }^{3}$
}

${ }^{1}$ Cent. Techn. Hortic. Tamatave (CTHT), Tamatave, Madagascar, ctht@moov.mg

2 CIRAD, Persyst, UPR Hortsys, TA B-103 / PS4, Blvd. de la Lironde, 34398 Montpellier Cedex 05, France

${ }^{3}$ CIRAD, ES, UMR Innovation, Ampandrianomby, BP 853, 99 Antananarivo, Madagascar

* Correspondence and reprints

Received 26 June 2013 Accepted 4 September 2013

Fruits, 2014, vol. 69, p. 1-18 (C) 2014 Cirad/EDP Sciences All rights reserved DOI: 10.1051/fruits/2013098 www.fruits-journal.org

RESUMEN ESPAÑOL, p. 18

\section{Experience from fifteen years of Malagasy lychee export campaigns.}

Abstract - Lychee on the European markets. With approximately $2.8 \mathrm{Mt}$ of annual global production, lychee constitutes a minor fruit in terms of production. The world production is mainly located in the northern hemisphere $(95 \%)$. However, most of the quantity exported to the EU comes from the southern hemisphere. In this context, with its 100,000 $t$ of annual production, Madagascar is ranked fourth in the producing world and first in the southern hemisphere producing countries. This rank is due to the fact that supplies in the EU are seasonal and mainly concentrated during the end of the year holiday season. This market can only be supplied in quantity by the Malagasy lychee because of its earlier date of harvest in the Indian Ocean. The lychee industry in Madagascar. Lychee cultivation in Madagascar dates from the early twentieth century. It is primarily grown in wet tropical lowlands of the island with some production in areas with a subtropical climate with dry and cool winters. The stand is not structured into orchards. Therefore, the volumes currently exported are based on a stand established by a multitude of small producers. The characteristics of Malagasy lychee export and the consequences of the production context on export are analyzed. Changes in European legislation on lychee importation. The regulatory changes since 1987 and the commercial developments since 1994 are reviewed by analyzing the resulting effects on the Malagasy lychee exports. Learning experience from fifteen years of Malagasy lychee export campaigns. Data on Malagasy lychee export campaigns from 1996 to 2012 and the history of the changes in volumes exported allow a close analysis of the factors affecting the Malagasy lychee industry. Success factors of the Malagasy lychee exports. These factors are related to securing market position and to the components of a marketing campaign (supply date to the European market, exported volumes and competition from produce from other countries). Conclusions. Lychees from Madagascar, although marketed for a very brief period, currently occupy the first rank on the European markets and have managed, through the development of transport logistics using very large-capacity cargoes, to eliminate all competition. However, this sector is mainly structured downstream and its production, which comprises a network of 30,000 small producers, has been neglected. This lack of intervention (boosting of production, improving crop management, etc.) upstream of the chain does not support sustaining the industry in the medium term.

Madagascar / Litchi chinensis / production data / production structure / exports / modes of transport / regulations / quality control

Expérience de quinze années de campagnes d'exportation du litchi malgache.

Résumé - Le litchi sur les marchés européens. Avec une production annuelle mondiale de 2,8 Mt, le litchi est classé comme un fruit mineur. La production mondiale se situe principalement dans l'hémisphère nord (95\%). Cependant, la plupart des quantités exportées vers l'UE provient de l'hémisphère sud. Dans ce contexte, avec ses 100.000 t de production annuelle, Madagascar est classé quatrième producteur mondial et premier producteur dans l'hémisphère sud. Ce rang est dû au fait que les approvisionnements en litchis de l'UE sont saisonniers et principalement concentrés au moment des fêtes de fin d'année. Ce marché ne peut être fourni en quantité que par les litchis malgaches en raison de la date de sa récolte dans l'Océan Indien. La production du litchi à Madagascar. La culture de litchi à Madagascar remonte au début du XX ${ }^{\mathrm{e}}$ siècle. Il est principalement cultivé dans les basses terres tropicales humides de l'île avec une certaine production dans les zones de climat subtropical à hiver sec et frais. Les zones de production ne sont pas structurées en vergers. Par conséquent, les volumes actuellement exportés sont basés sur une production alimentée par une multitude de petits producteurs. Les caractéristiques de l'exportation du litchi malgache et les conséquences du contexte de production sur son exportation sont analysées. Changements de la législation européenne concernant l'importation de litchi. Les modifications réglementaires de l'UE depuis 1987 et les développements commerciaux depuis 1994 sont présentés en analysant leurs effets sur l'exportation du litchi malgache. Enseignement de quinze années de campagnes d'exportation du litchi malgache. Les données sur les campagnes d'exportation malgaches du litchi de 1996 à 2012 et l'évolution des volumes exportés pendant ces années permettent une analyse approfondie des facteurs affectant la filière du litchi malgache. Facteurs de réussite de l'exportation du litchi malgache. Ces facteurs sont en relation avec la sécurisation du marché et les caractéristiques d'une campagne de vente (date de l'offre sur le marché européen, volumes exportés et concurrence des produits provenant d'autres pays). Conclusions. Les litchis de Madagascar, bien que commercialisés pendant une période très brève, occupent actuellement le premier rang sur les marchés européens ; grâce au développement d'une logistique de transport utilisant des cargos de très grande capacité, ils ont réussi à éliminer toute concurrence. Cependant, ce secteur est structuré principalement en aval et les conditions de sa production, qui dépend d'un réseau de 30.000 petits producteurs, ont été négligées. Ce manque d'intervention (renforcement de la production, amélioration de la gestion des cultures, etc.) en amont de la chaîne n'aide pas à soutenir la filière à moyen terme.

Madagascar / Litchi chinensis / donnée de production / structure de production / exportation / modes de transport / réglementation / contrôle de qualité 


\section{Introduction}

Distributors of tropical fruit widely consumed on the European markets are looking to secure their supplies by diversifying sources either by promoting and supporting the development of existing channels or through the establishment of subsidiaries in geographically well-positioned and politically stable countries. Thanks to this policy the relevant product markets are more stable and these products have entered the category of current consumption without strong business seasonality. As regards the products of tropical or inter-tropical zones, the security of supply to European markets of products (bananas or pineapples, for example) would not have been possible without the following improvements:

- maritime transport (duration, frequency, port logistics),

- storage conditions of the products (new conservation techniques),

- cultivation techniques and improved varieties (mastery of flowering, time of harvest, etc.),

- the establishment of unit industrial production to secure supplies.

However, because the seasonality of tropical fruits is too great or because they require savvy or very specific consumers (ethnic markets) or because their cost is too high and fluctuating (granadilla, lychees, starfruits, etc.), the volumes traded are low; the market shares are rarely secure because these products are not a necessity in the eyes of consumers and their withdrawal from commercial networks would be without significant economic consequences.

Given this situation, marginal or niche products have not benefited from the same development as products in high demand. These remain most often concentrated in networks of organized or unorganized small producers and are often disconnected from market expectations (lychees and mangos, for instance). However, these horticultural crops, when they are produced by small farmers, guarantee significant cash income and employment. In fact, the monetization of rural economies remains a prerequisite for both the access of the population to basic social services (health and education) and the establishment of business trends. Therefore, the lack of security in the horticultural industries is a threat to the food security of these populations.

Furthermore, the sustainability of these horticultural sectors is affected by a number of constraints that are related to the market access targeted. These are constraints, whether controllable or not by the farmers concerned (exporters, collectors, etc.), which will have to be quickly taken into consideration by the farmers, with the actors of the sector, in order to ensure continued supply of foreign markets and secure their income. These are linked with:

- The tightening of food regulations in importing countries with a stronger control of products and the implementation of new guidelines that aim at protecting the consumer (business type certifications: ASTA, GlobalGAP (e.g., EurepGAP ), IFS, BRC, for instance, and EC 178/2002 regulations 882/ 2004 and 852/2004, etc.);

- More strict quality requirements by importers with the implementation of internal controls to ensure compliance with business and regulatory quality standards imposed by the importing country;

- Strengthening of the competition in other producing countries through the improvement of their product competitiveness compared with those of another origin, by lowering production costs and increasing productivity;

- Varying annual production and harvest period (markedly alternating or delayed harvesting period) in relation to climate change observed in recent years (drop in rainfall or hurricane risk).

The Malagasy lychee industry is facing these constraints and, given the type of actors involved in its operation, it constitutes a particularly interesting study design.

Therefore, based on 15 years of lychee data collection in Madagascar and in the European markets, the objective of our article was to analyze the strategies implemented by Malagasy lychee industry operators in order to secure it, and to highlight their potential weaknesses. 


\section{The lychee on the European markets}

With approximately $2.8 \mathrm{Mt}$ of annual global production, lychee appears to be a minor fruit in terms of production compared with other tropical fruits. This production is very heterogeneous among the 16 major producing countries with the net dominance of China, which comprises nearly $70 \%$ of the world production (table I) [1, 2]. The distribution between the northern hemisphere and the southern hemisphere is totally unbalanced, with $95 \%$ of world production by the north. In this context, with 100,000 t of annual production, Madagascar is ranked fourth among the producing countries and ranked first in the southern hemisphere producing countries.

Regarding exports, the situation is totally different and totally disconnected from the production because the majority of the exported volumes to European countries come from the southern hemisphere (table II).
By the annually marketed volumes (about 25,000 t), lychee is secondary on the European markets compared with banana, pineapple or mango, for example (table III).

The supply of lychees to European markets is seasonal and is linked to harvesting periods spread only over a short period of time between production areas in the northern hemisphere and the southern hemisphere (table IV) [3]. Given this seasonality, supply to the markets is not spread throughout the year and the main supply is, on the one hand, the export from the Indian Ocean area at the end of the year and, on the other, a more diverse supply from the northern hemisphere from April to September. The main producing countries in the Indian Ocean are Madagascar, South Africa, Mauritius and Réunion. Exports from Mexico, Australia, China, Vietnam and India are still very limited [4]. Widely varying production costs and modes of transport (table $V$ ) from exporting countries to destination countries explain the variations in market prices throughout the year.

Table I.

Global production distribution of lychees [1, 2].

\begin{tabular}{lc} 
Country & Production $(\mathrm{t})$ \\
\hline China & \\
India & $1,910,800$ \\
Vietnam & 425,000 \\
Taiwan & 156,000 \\
Thailand & 80,000 \\
Nepal & 43,000 \\
Bangladesh & 14,000 \\
Pakistan & 13,000 \\
Mexico & 3,000 \\
Israel & 4,000 \\
USA & 1,200 \\
& 600 \\
Madagascar & \\
South Africa & 100,000 \\
Australia & 7,000 \\
Réunion & 6,000 \\
Mauritius & 10,000 \\
& 3,500
\end{tabular}




\section{Table II.}

Volumes and main origins of lychees annually imported by Europe. Average calculated over 10 years (2000 to 2010).

\begin{tabular}{lc} 
Origins of importations & Volumes of importations $(\mathrm{t})$ \\
\hline \multicolumn{1}{c}{ Southern hemisphere } \\
Madagascar & 19315 \\
South Africa & 3590 \\
Mauritius & 182 \\
Réunion & 187 \\
Total importations $\quad$ Northern hemisphere & 23087 \\
& \\
Thailand $\quad 1816$ \\
Israel & 733 \\
China & 191 \\
India & 409 \\
Spain & 907 \\
Total importations & 4056 \\
Source: Eurostat (from 2000 to 2010). &
\end{tabular}

\section{Table III.}

Tropical fruit importations on the European markets (t) in 2010 and 2011.

$\begin{array}{lcc}\text { Tropical fruits } & 2010 & 2011 \\ \text { Papaya } & 9,000 & 10,000 \\ \text { Lychee, passion fruit, pitaya, etc. } & 28,300 & 29,700 \\ \text { Mango, guava, mangosteen } & 147,500 & 145,480 \\ \text { Avocado } & 183,800 & 171,700 \\ \text { Pineapple } & 457,600 & 468,300 \\ \text { Lemon } & 574,700 & 595,100 \\ \text { Orange } & 1,974,700 & 1,923,800 \\ \text { Banana } & 2,232,000 & 2,222,000\end{array}$

Source: Eurostat (2010 et 2011).

\section{The lychee industry in Madagascar}

\subsection{The Malagasy lychee cultivation}

Lychee, of the Sapindaceae family, is native to China. It was introduced to Réunion in 1764 by Joseph-François Charpentier de Cossigny de Palma. From there, it was then planted in Madagascar by A. Michaux in 1802 in the context of creating acclimatization gardens for fruit species [5]. The development of this culture was late and is linked with the arrival of Asian and Creole settlers on the east coast of Madagascar in 19401950 .

This culture has developed mainly in wet tropical lowlands of the island with some introductions in areas with a subtropical climate with cool and dry winters (figure 1). Therefore, the phenology of the tree varies greatly from one area to another and the 
Table IV.

Production calendar of main lychee producing countries [3].

Producing country Mar Apr May June July Aug Sept Oct Nov Dec Jan Feb
North hemisphere
China
India
Taiwan
Thailand
Vietnam
Nepal
Bangladesh
USA
Mexico
Israel
Spain
South hemisphere
Réunion
Mauritius
Madagascar
South-Africa
Australia

\section{Table V.}

Lychee transportation for European market supply.

\begin{tabular}{|c|c|c|}
\hline Exporting country & Supplying by air & Supplying by sea \\
\hline \multicolumn{3}{|c|}{ North hemisphere } \\
\hline China & Yes & Yes \\
\hline Thailand & Yes & Yes \\
\hline Mexico & Yes & Yes \\
\hline Israel & No & Yes \\
\hline Spain & No & Yes \\
\hline \multicolumn{3}{|c|}{ South hemisphere } \\
\hline Madagascar & Yes & Yes \\
\hline South Africa & Yes & Yes \\
\hline Mauritius & Yes & No \\
\hline Réunion & Yes & No \\
\hline Australia & Yes & No \\
\hline
\end{tabular}

spread of the flowering and the harvesting years 1940 to 1950 by the settlers, have been depend on the latitude and altitude of the identified [6].

plantation.

The trees in rural areas come mostly from

The stand is not structured into orchards. layers and are planted near villages or in the Only a few plantations, established in the family fields. Despite the existence of recent 
Figure 1.

Lychee production area location in Madagascar.

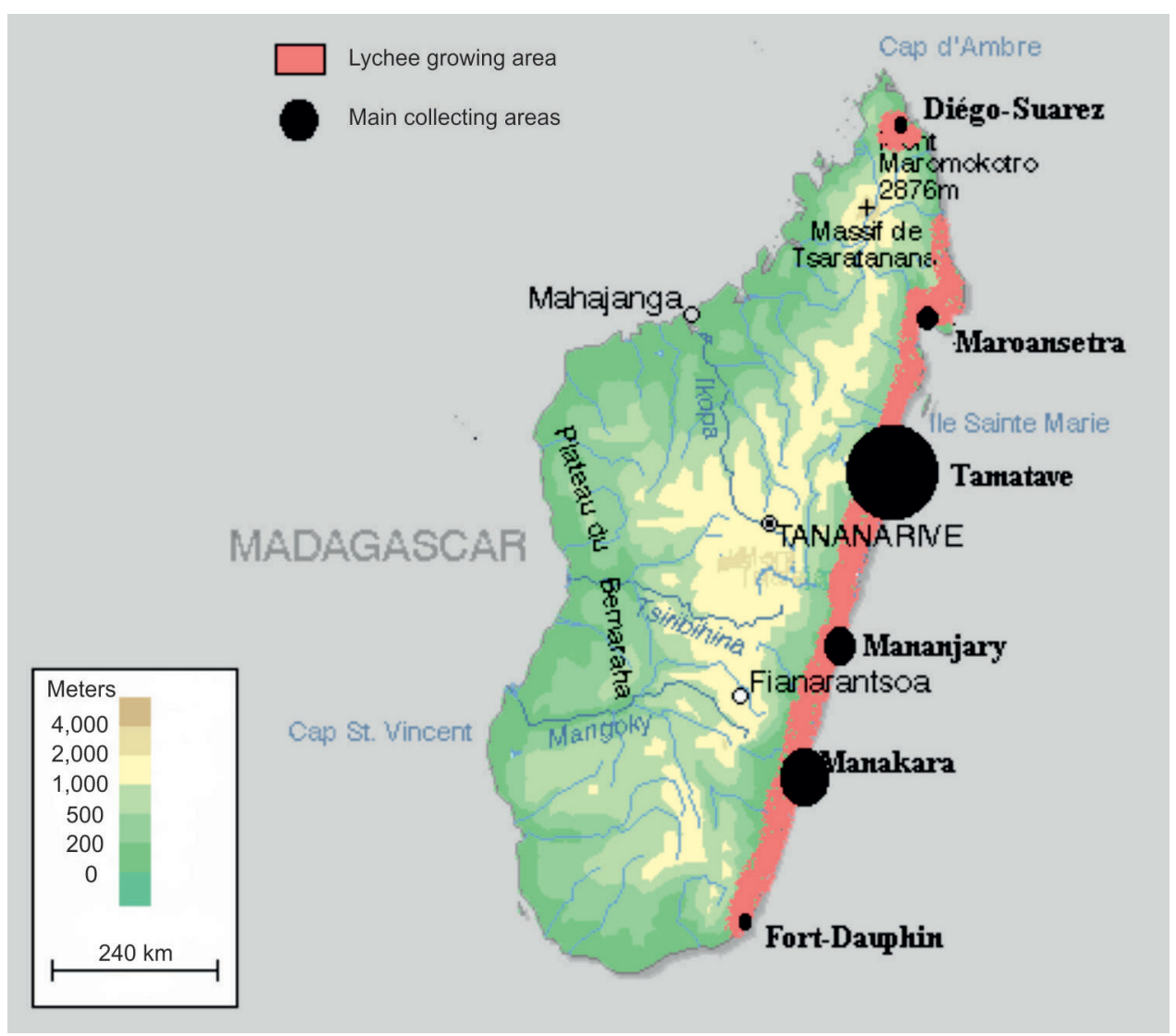

plantations, the current production comes from fruit harvested from old trees whose size is, for some, regulated by the regular hurricanes on the east coast.

On a cultivar basis, it is difficult to state that Madagascar has clearly identified varieties. There are predominant phenotypic characters in the population, which leads to the conclusion that there is a dominant variety (Kwai Mee) [7]. However, given the identification of trees that are early or late, producing fruit with smooth shells, with parthenocarpic fruits, etc., it is easy to surmise that uncontrolled introductions also occurred.

Throughout the colonial period (18891960), production grew throughout the east coast without considering any prospect of commercial exploitation of the resource. Therefore, the dynamics of planting could be based on a wish for diversification and / or reproduction of the environment that was created by the settlers before.
Therefore, in the absence of substantial planting programs undertaken after the colonial time, the volumes currently exported are only based on the use of a stand set up by a multitude of small producers who are disconnected from the external market expectations.

\subsection{The major production areas of Malagasy lychee}

Although lychees can be found along the entire east coast of Madagascar, there are three main producing areas where there is an effective mobilization during the export campaign: Tamatave, Manakara and FortDauphin (figure 1, table VI).

\subsubsection{Tamatave}

Two lychee production areas that are categorized by altitude are identified in the Tamatave region. 


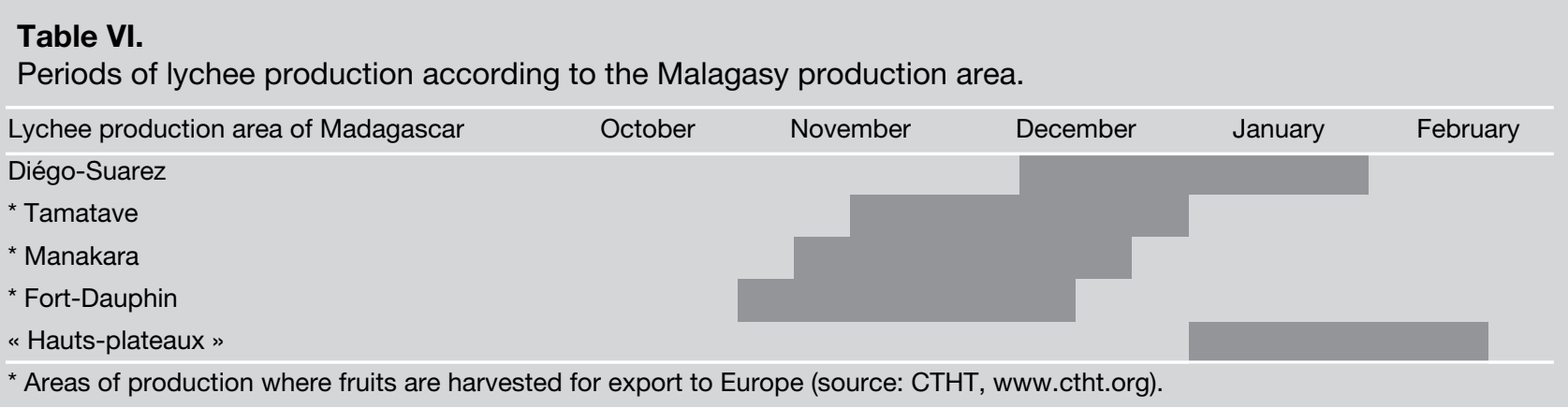

A low-lying coastal area ranging from Soanierana Ivongo, north of Tamatave, to Mahanoro, south of Tamatave, represents a strip of production area of $300 \mathrm{~km}$ in length by $30 \mathrm{~km}$ wide giving around a $9,000-\mathrm{km}^{2}$ production area; Tamatave is located at the center of that strip. The inland area is penetrated by some secondary roads and an extensive network of rivers. In this area, the lychee stand consists of isolated lychee trees and small plantations (100 to 300 trees); the trees being exploited are often old trees located on poor soils. In this area, production potential varies depending on the year because lychee follows a cycle of alternating high and low production, and it is between 30,000 $\mathrm{t}$ and 40,000 t.

An upland area is located north of Tamatave and corresponds to the region of Vavatenina. The asphalt and dirt roads that penetrate this area are few and not suitable for vehicles; therefore, handling and transport of products remain difficult. This region is mainly mobilized only towards the late end of the collecting campaign (early December) for export by container. The lychee stand of that area is less abundant than that of the coastal area and consists mainly of isolated stocks and small groups of trees. Its production potential is between 3,000 $\mathrm{t}$ and 5,000 t.

The potential of this region lies in its proximity to the port of Tamatave and is the one most mobilized for export (96\%).

\subsubsection{Manakara}

In the Manakara region, there are two main production areas, one located north of the city of Manakara and another south.
In the northern area, which extends up to Mananjary, production is later than that of the southern area. Lychees are easily accessible because they are located near or along practicable roads. Moreover, the population of lychee trees is partly structured in small stands and into orchards, and access to the product is facilitated.

Production potential is significant given the size of the area and the age of the trees. This is estimated to be between 5,000 $\mathrm{t}$ and $10,000 \mathrm{t}$ depending on the year.

Given the absence of a deep-water port in the region, lychees in this region are currently collected mainly for export by plane from Antananarivo or they are transported by road and then by boat upon their arrival at the port Tamatave. The rest of the volume is either consumed within the area or destined for the local markets.

The production potential mobilized for export from this area currently accounts for only $4 \%$ at most of the total volume of exported Malagasy lychees.

\subsubsection{Fort-Dauphin}

In the Fort-Dauphin region, there are two major lychee production areas, an early production area and a late production area. This is mainly due to agroclimatic differences which characterize these areas since the cultivars planted are the same.

The early production area is located west of the city of Fort-Dauphin, in the region of Soanierana. In a normal year, the production potential is estimated at $150 \mathrm{t}$ of exportable products. Lychees are easily accessible as they are located along main or secondary roads. Moreover, trees are often grown in 
small clusters. The late production area is located north of the city of Fort-Dauphin in the region of Nahampona and Ranomafana. Production potential is higher than in the region of Soanierana; it is estimated at $1,000 \mathrm{t}$ a year. In that area, lychees are not easily accessible because the secondary roads are not practicable and some stands are in very remote areas. This stand is, at present, not used in export transactions despite the existence of a deep-water port.

Given the small volumes available, only lychees in the early production area are exploited for export by air. The rest of the volumes produced are either consumed locally or go to local markets.

The production potential mobilized for exports is less than $0.2 \%$ of the volume of Malagasy lychees exported.

\subsection{Characteristics of the Malagasy lychee exports}

The first exports of Malagasy lychees began in 1960 [8, 9]. Lychees initially were exported fresh by air; their marketed quantities were low at that time and this fruit appeared on the European markets as a luxury reserved for certain customers of Asian origin.

Despite the limited quantities exported, lychee was rapidly integrated into the farming systems of the east coast of the country since the fruit was available from FortDauphin in the south to Antsiranana (Diégo-Suarez) in the north.

The authorization granted by the European Union in 1987 to import lychees treated with sulfur dioxide has dramatically changed the stakes in this sector. This postharvest treatment, which ensures lychee preservation for more than 4 weeks $[10,11]$ allows shipments of fruits by sea and thus has greatly reduced the price of lychee imported by Europe [12].

In a few years, Madagascar has become the leading lychee exporting country thanks to this change in the means of shipment, which allowed a better marketing of the fruit [13]. In order to meet this growing demand, the number of operators has increased from
5 to more than 30 and the collection area has been considerably extended. However, to deal with the tightening of regulations in Europe, the growing demands of consumers and the emergence of new exporting countries, the Malagasy lychee industry has gradually become more structured around objectives that aim to improve the quality of lychee exported and to ensure compliance with the maximum residual sulfur content allowed upon arrival in Europe.

Currently, over $96 \%$ of lychees produced in Madagascar are exported to Europe, the remaining $4 \%$ being mainly exported to Dubai and Mayotte. Other potentially promising markets (USA, Canada, India, China, Japan, etc.) are inaccessible either because of the transit times, or because their regulations do not allow the importation of lychee treated with sulfur dioxide.

\subsection{Implications of the context of the Malagasy lychee production export}

Although domestic production is estimated at $100,000 \mathrm{t}$, it is the production in the Tamatave region which is mainly mobilized for export by sea and air. However, the lychee export is not annually secure and there is no guarantee that markets can be effectively supplied due to a number of elements that characterize the production in this region:

- This production is distributed between 20,000 and 30,000 small producers located throughout the region.

- The lychee being a product of collection (rather than production), production costs are very low: the labor is mainly from within the family and external labor is very cheap (around US\$ 1 per day); no agricultural input is used. The area is subject to significant climate risk characterized by a long hurricane season (from January to May), and given the fragility of the lychee branches, strong winds strongly affect production.

- The annual climate changes (temperatures and rainfall) in this region disrupt the phenology of the tree and modify the blooming period, and thus the fruit harvest. 
This has led the actors (importers and exporters) of the lychee industry to make certain decisions:

- To maintain the current boom in the Malagasy lychee production in order to keep production costs low at export and to limit the effects of climate risks on the production by diversifying the production areas.

- To support the establishment of a mechanism which allows fruiting monitoring and the setting up of an opening date for the fruit collecting campaign [14].

- To establish a collection network compatible with this boom in production (2,000 collectors mobilized annually).

- To find a way of shipping by sea that is fast enough to deal with possible hazards related to the production (harvest date).

\section{Changes in European legislation for lychee importation}

\subsection{Regulatory changes}

Since 1987, the "lychee" sector is subject to various regulations that require the actors to regularly implement actions to meet them. These major changes are presented below.

- 1987: authorization granted by France and the European Union to import lychees treated with sulfur dioxide by setting the MRL (Maximum Residue Limit) of sulfur to less than $10 \mathrm{mg} \cdot \mathrm{kg}^{-1}$ in the pulp and less than $250 \mathrm{mg} \cdot \mathrm{kg}^{-1}$ in the pericarp. In fact, sulfur is present as $\mathrm{SO}_{2}$ in lychee following its fumigation by burning flowers of sulfur; the maximum level is set by regulation on additives (Directive 95/2/EC of 20-021995 for additives other than colors and sweeteners)

- January 2005: implementation of the EC Regulation $\mathrm{N}^{\mathrm{O}} 178 / 2002$ on food safety. This regulation ensures the quality of foodstuffs intended for human consumption and animal feed. This ensures the free movement of safe and healthy food in the domestic market. Operators apply food laws at all stages of the food chain in the production, processing, transport, distribution and supply of food. Similarly, operators are in charge of ensuring product traceability at all stages of production, processing and distribution.

- March 2005: implementation of the ISPM N¹5 (International Standards for Phytosanitary Measures) Directive for the regulation of wood-based packaging materials in international trade. This standard describes phytosanitary measures to reduce the risk of introduction and / or spread of quarantine pests associated with coniferous and nonconiferous raw wood packaging material (including dunnage) used in trade. Malagasy lychees being exported on pine wood pallets, this regulation applies to the sector.

- January 2006: implementation of the EC Regulation $\mathrm{N}^{\circ}$ 852/2004 on foodstuff hygiene. This regulation aims at ensuring the hygiene of foodstuffs at all stages of the production process, from primary production to the final consumer. All food business operators will ensure that all steps which they are in charge of, from primary production to sale or provision of food to the final consumer, are carried out in a hygienic manner, in line with the provisions of the regulation.

- January 2006: implementation of the EC Regulation $\mathrm{N}^{\mathrm{O}} 882 / 2004$ on the national systems of sanitary controls. This regulation aims at filling gaps in the existing legislation on official food control through a harmonized EU approach to the design and implementation of national control systems. Official controls are defined as "any form of control by the competent authority to verify compliance with the legislation on foodstuffs. State members will designate the authorities which are competent to carry out official controls".

\subsection{Commercial developments}

Some trends and commercial requirements have significantly changed the functioning and organization of the lychee sector:

- 1994: mobilization of conventional vessels for transport to Europe. These refrigerated ships have a high cargo capacity (between 
2,000 $\mathrm{t}$ and 6,000 t) and a high cruise speed (21 knots at maximum) which allows them to reach Europe faster than container ships. When the production period allowed, this time saving allowed the Malagasy lychees to arrive in Europe before December 24.

- 2006: EurepGAP (renamed "GlobalGAP" in 2007), a private collective standard for the certification of the production process. This standard was established in 1997 by the European food retailers as a response to the concerns of European consumers following several outbreaks [15]. In order to ensure the safety of exported food products, producers must be certified either individually (option 1) or as a group (option 2). Quality management systems should be developed to ensure the safe use of pesticides and compliance with hygiene and handling standards. Finally, exporters must be able to trace back a given production from the specific operating production in which it was obtained, to ensure that the product complies with the standard.

- 2009: strengthening of the control of supermarkets (mainly German) of sulfur residues before the marketing of lychees. This reaction is due to exceeding residues during control checks in 2008. However because of recurring exceeding residues, major German retailers chose not to market Malagasy lychee during the 2010-2011 season, to reassure their customers and ensure respect for their commercial commitments.

\section{Learning experience from fifteen years of Malagasy lychee export campaigns}

\subsection{Justification of the monitoring}

The share of lychee in the farmers' economy of the east coast of Madagascar is an important and necessary income for the households concerned. The European Union has supported the development of this sector from 1996, entrusting the CTHT (Techn. Hortic. Cent. Tamatave, Madagascar) with the responsibility of carrying out actions at all stages of the value chain (from production to export). In this context, several provisions for monitoring and study have been implemented annually in Madagascar (before and during the lychee collection campaign) and in Europe (during the marketing campaign). The objective of these actions was to provide key actors in the sector with information that will improve its competitiveness and support its effort to become structured.

\subsection{General features of the lychee export campaigns from 1996 to 2012}

Analysis of Malagasy lychee campaigns from 1996 to 2012 indicates that the course of these campaigns has been systematically different from one year to another regarding the start date for the collection, the volumes exported, the planning of the production arrival in Europe, etc. (tables VI and VII).

Given the factors that cannot be controlled (mainly climatic and physiological) that influence the harvest date, exporters are not able to plan ahead with certainty either the course of a campaign or its eventual commercial success. Any success of a campaign is therefore based on the adaptive capacity of the actors to rapidly and effectively respond to the specific conditions of each campaign.

Qualitatively, the average diameters of lychees from Madagascar have varied depending on the campaign from (29 to 31.6) $\mathrm{mm}$ (table VIII). This lack of consistency has not been linked to the overall rainfall but more to the distribution of rainfall and to the length of dry periods without rain prior to harvest, as producers do not carry out any care or watering of the trees throughout the year.

During the storage period, the product undergoes desiccation of between $12 \%$ and $14 \%$ [16], and thus up to $1 \mathrm{~mm}$ diameter reduction. Therefore, the diameter of lychees marketed rarely exceeds $30 \mathrm{~mm}$. This puts the Malagasy lychee in a quality grade category significantly lower than that of its competing origins such as South Africa. This positioning of the product at a low price and perishability led European 


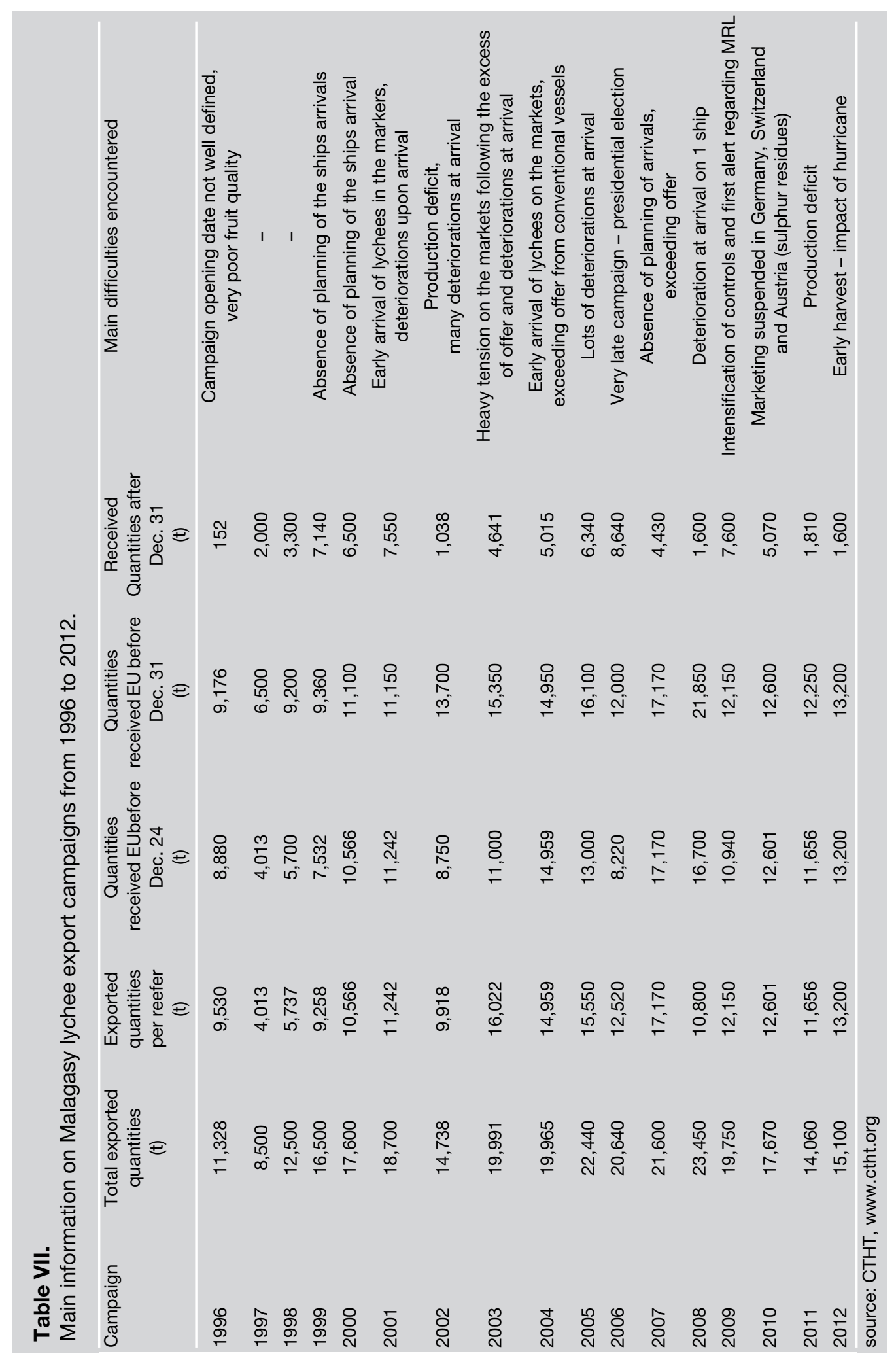


M. Jahiel et al.

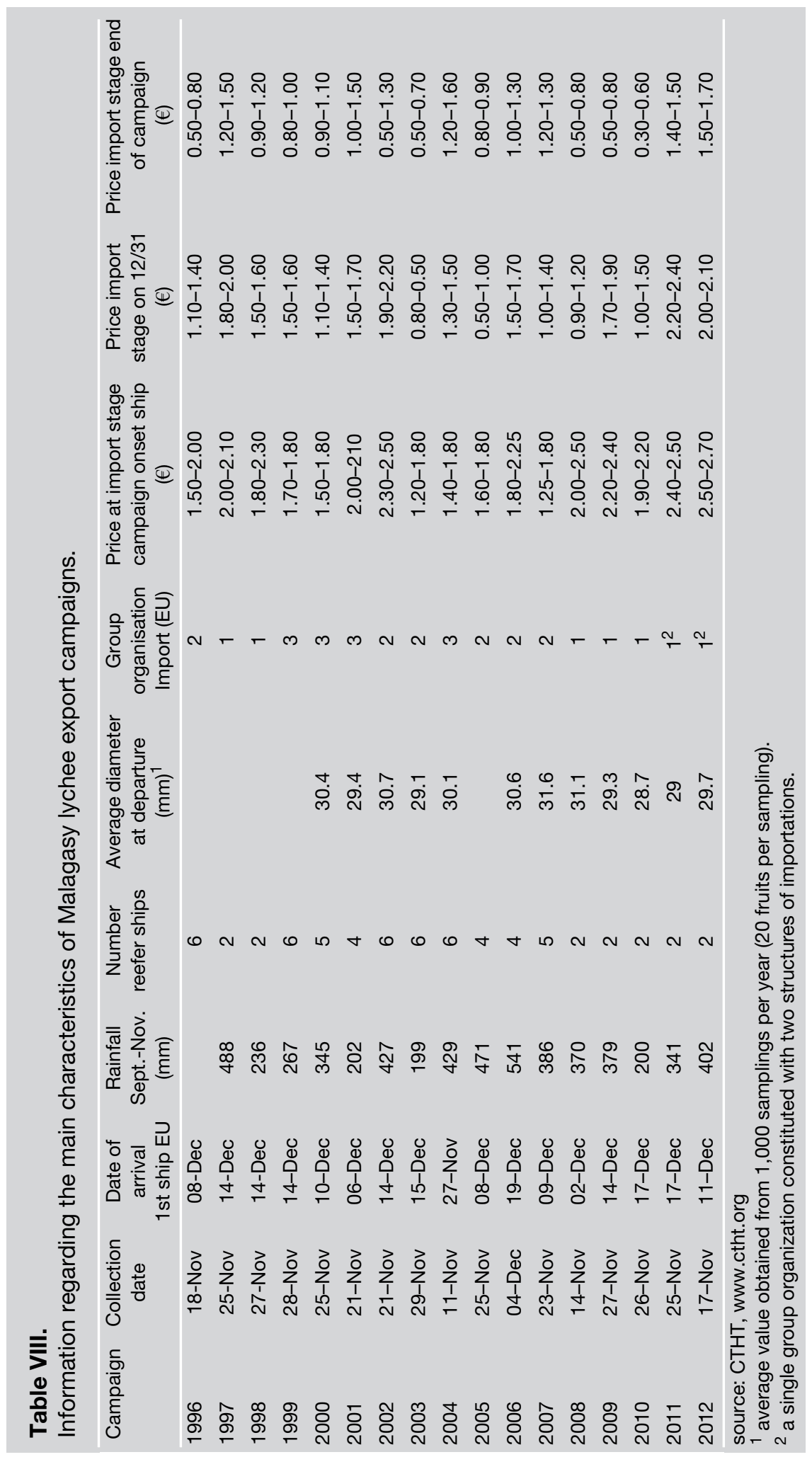

12 Fruits, vol. 69 (1) 


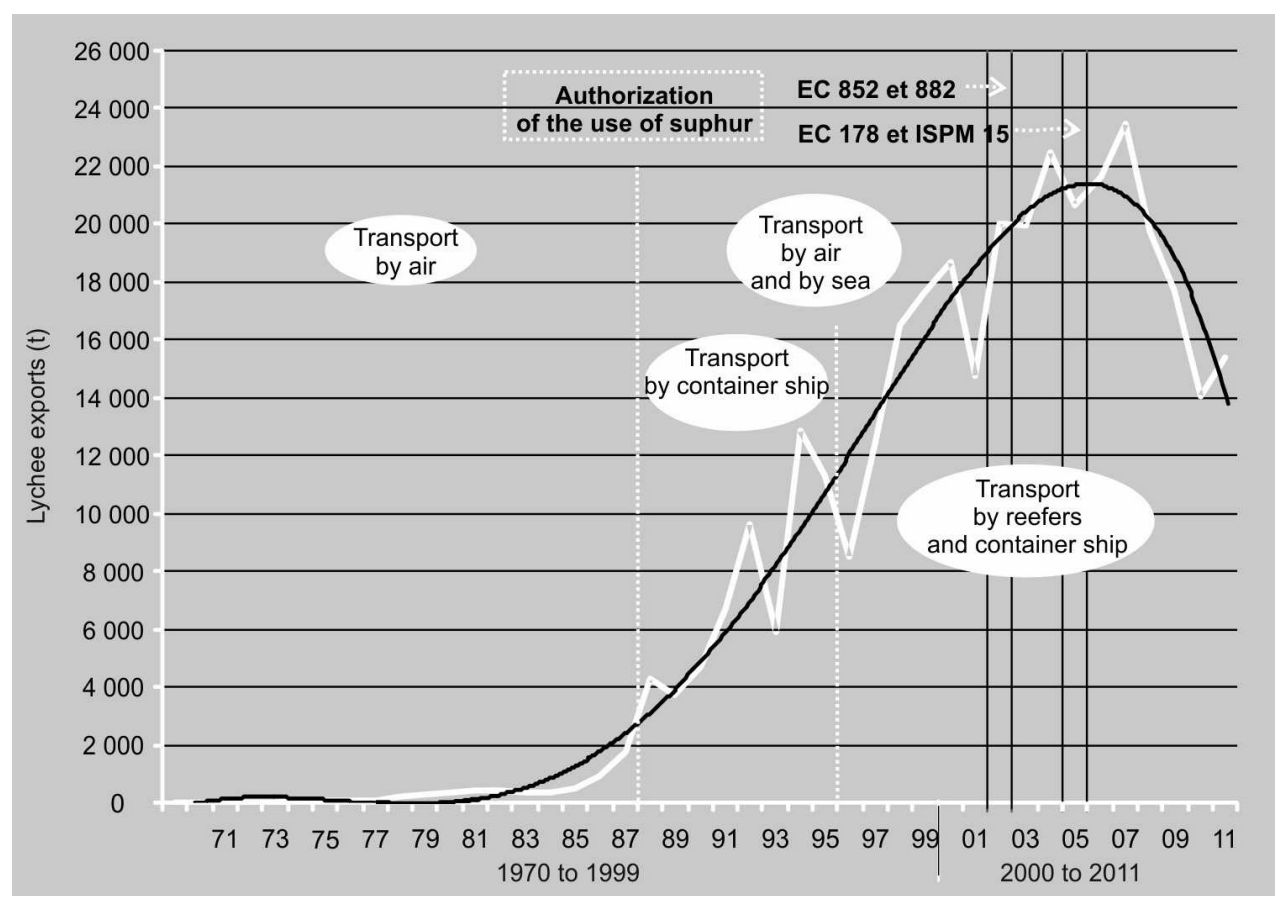

importers to prefer supermarkets in order to sell large volumes transported by conventional boats (reefers) with a marketing strategy of associating this product with the end of the year holiday season targeting a consumer looking for a festive and inexpensive product.

Regarding the collection periods, we found that they strongly differed from one year to another, with differences of up to 3 weeks between the earliest and the latest harvest [14]. This confirms that the lychee flowering and fruiting are dependent on climatic factors, and more specifically on the temperature [17, 18].

\subsection{Changes in export volumes}

Monitoring of the quantities exported since the beginning of the marketing of Malagasy lychees on the foreign markets shows a bell curve with a steady growth for 10 years with a peak in 2007 , with $23,000 \mathrm{t}$ of lychee exported (figure 2), and then a rapid fall in the quantities exported to Europe after this date.

Phases of growth in export volumes can be linked with the modes of transportation that were used during these campaigns. They are divided into three stages:

- 1972 to 1987: during this period, fresh lychees were exported by air to France. The fruit preservation periods being very short (3-4 days), exported volumes remained low.

- 1987 to 1994: during this period, lychees were exported by air and refrigerated container ships. This boat transport was made possible thanks to the authorization granted by France and the EU, for importing sulfur dioxide-treated lychees. Sulfur is currently the only postharvest treatment that can ensure preservation of lychee for more than 4 weeks. In addition, the decrease in the transportation costs associated with a low cost of production and postharvest operations has allowed a considerable development of the export volumes.

- 1994 to 2012: during this period, lychees were exported by air, by container ships and refrigerated cargo (conventional type). Refrigerated transport vessels have reduced the travel duration to Europe [(15 to 17) days] and thus led Madagascar to put large amounts of fruit in the European markets before Christmas. This opportunity has significantly changed the positioning of the
Figure 2.

Changes in Malagasy lychee exports to Europe. 
Figure 3.

Relationship between the quantities exported from Madagascar by conventional ships and those received in Europe before Christmas.

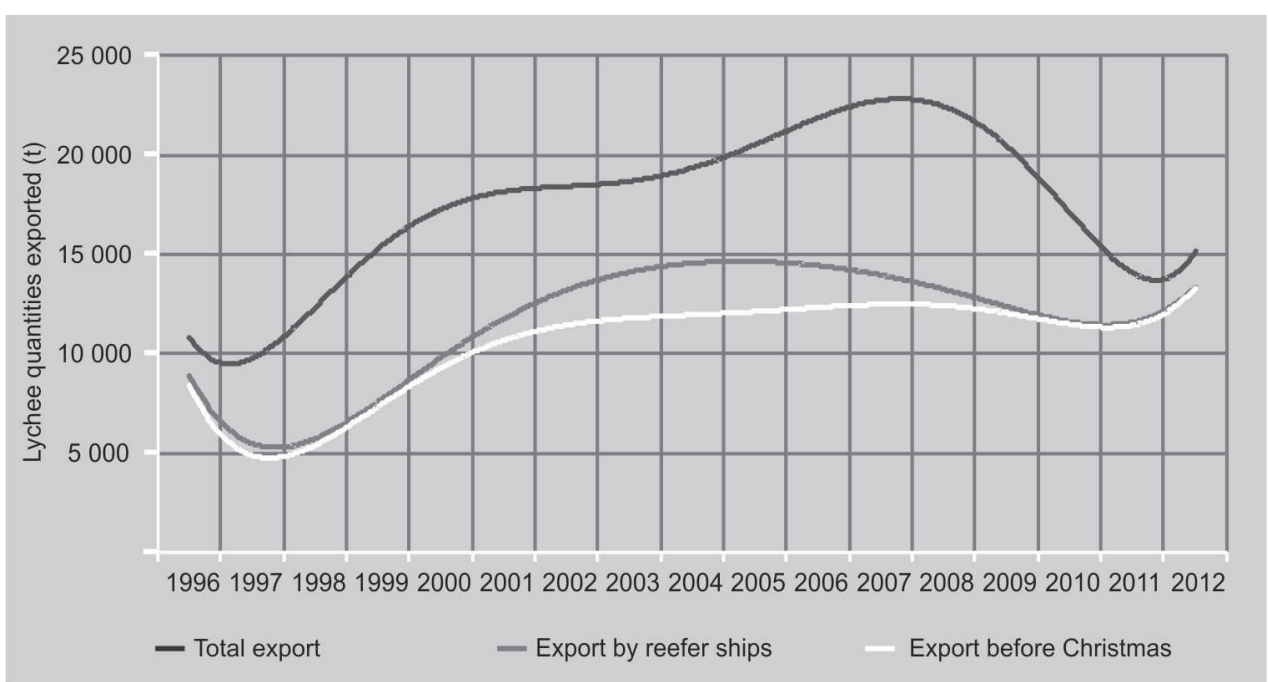

Malagasy lychee on the European market as it has gradually moved from a niche exotic type of product enjoyed by only certain types of communities to an appealing product for supermarket retailers which have associated it with the end of the year festivities.

The curve analysis revealed a significant drop in exported volumes after 2007 (figure 2). This drop is linked with the implementation of new regulatory and commercial provisions from 2006 (figure 2), mainly in relation to the sanitary safety of the consumers (see 3.1.).

Sulfur treatment is regulated at the European level by the Minimum Risk Levels (MRL) in the pulp set at $10 \mathrm{mg} \cdot \mathrm{kg}^{-1}$; following the need to reassure consumers about respect for the MRL and regulatory compliance, the residue checks before marketing have been intensified and systematized, mainly by distributors based in Germany (Aldi and Lidl distributors, for example). From 2009, the controls were strengthened given that the MRL was consistently exceeded; in the German, Swiss and Austrian markets, the marketing of lychee was then suspended, forcing importers to transfer the volumes provided for these markets to other countries where trade controls were less important, and this caused a saturation of the latter and a lowered price.

In order to regain the confidence of these markets, and establish an action plan in Madagascar in order to reduce the risks of fruit export not meeting the MRL and to secure the industry, importers and exporters were forced to lower export volumes. This has reduced the pace of work in the packing stations, which then have been able to strengthen internal control procedures, thus the fall in export volumes noticed after 2010 (figure 2).

\section{Success factors of the Malagasy lychee exports}

\subsection{Securing the commercial positioning}

Analysis of Malagasy lychee export campaigns from 1996 to 2012 (figure 3) indibefore Christmas, lychee importers favored transport with refrigerated conventional vessels (reefers). This may have three explanations: i) this type of transport is the only means of maritime transport which allows a trip (Madagascar - Europe) in less than 20 days, ii) transport costs are clearly lower than those of the refrigerated container ship, and iii) lychee treatment and handling were concentrated near the port of Tamatave where this type of vessel can be loaded.

Moreover, the amount of lychees carried by these vessels has steadily increased over the last ten years as it has increased from cates that, in order to ensure market supply 

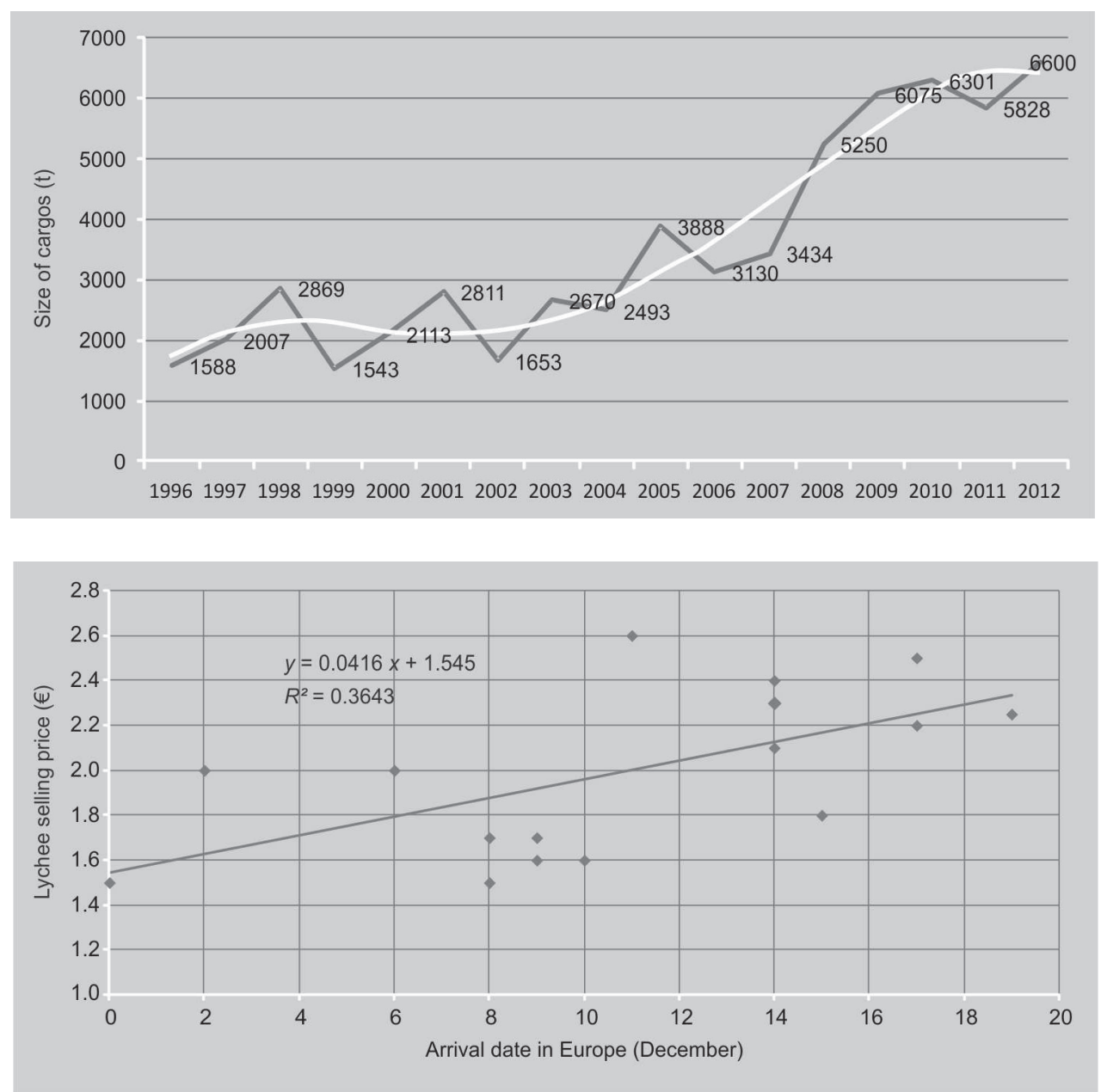

2,000 t to over 6,000 t per vessel (figure 4). This improvement allowed the lychee production:

- to withstand the increase in the shipping cost (due to the increase in fuel price),

- to completely get rid of any competition because no country in the area of the Indian Ocean has the sufficient production to use such vessels in a very short period of time (table I).

\subsection{The current criteria for a successful marketing campaign}

Two criteria for a successful export campaign of the Malagasy lychee were studied: (i) the influence of ships' arrival date in
Europe and, consequently, the organization of the fruit collection in Madagascar, and (ii) the volumes received after the end of the year holidays (after January 1).

The analysis of the relationship between the time of arrival of the first boats in Europe and the selling price of a kilogram of lychees hand, for the arrival of lychees before December10, the market does not guarantee sales prices superior to $2 € \cdot \mathrm{kg}^{-1}$ at the beginning of the campaign, and on the other hand, the ideal time of arrival of the first exported lychees by boat to the European markets is between December 11 and December 16 (figure 5).

However, it turns out it is not possible to guarantee for sure the arrival of the boats on the French market shows that, on the one
Figure 4.

Average changes in the sizes of cargoes used to transport lychees from Madagascar to Europe between 1996 and 2012.

Figure 5.

Lychee selling price level at the Malagasy campaign onset according to the arrival date of the first ship in Europe. 


\section{Jahiel et al.}

Figure 6.

Duration in number of days between lychee collecting onset in Madagascar and arrival of the first ship in Europe.

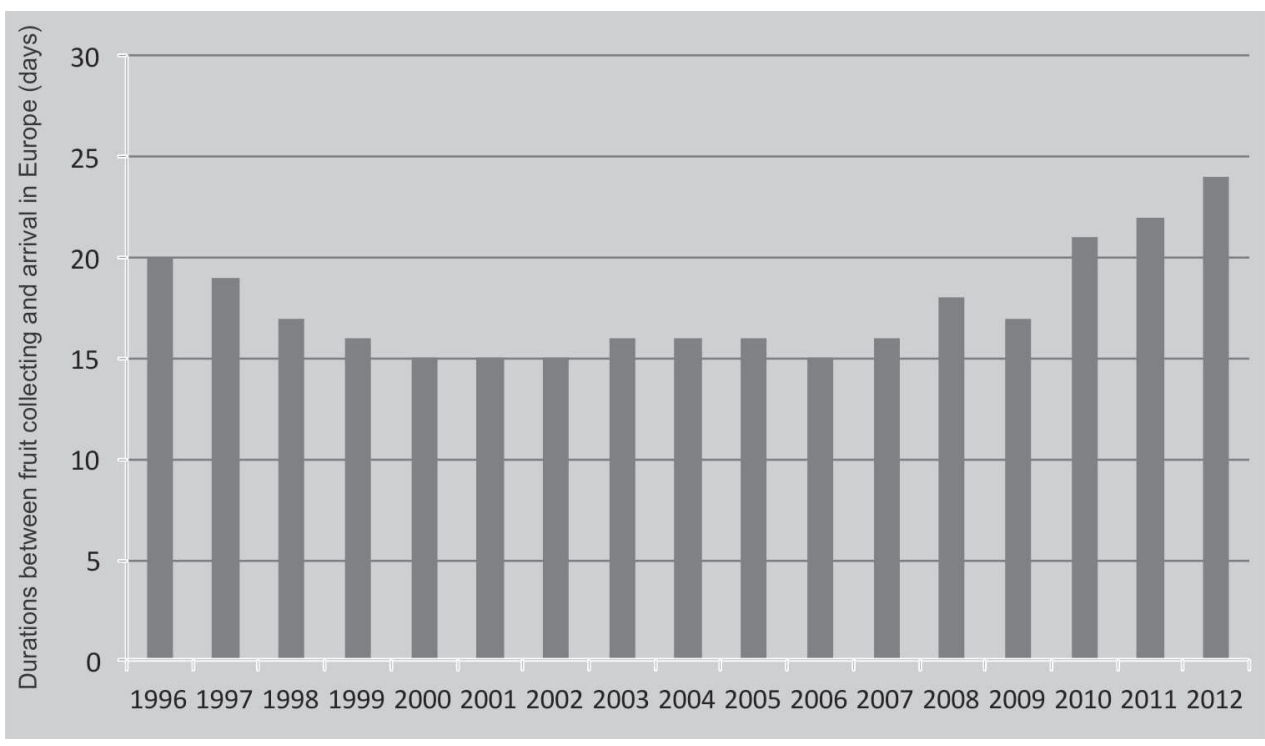

before the Christmas festivities and the time of arrival of conventional vessels varies annually for various reasons:

- The onset of flowering being influenced by climatic factors, lychee fruiting varies each year. Thus, during the 16 years of our study, a three-week duration was recorded from the earliest campaign season (November 11) and the latest campaign (December 4) in the region of Tamatave.

- Because of the insecurity in the vicinity of the Horn of Africa and the establishment of security measures aimed at reducing risks of piracy, importers thus prefer the southern route via the Cape of Good Hope to reach Europe. Since 2010, this choice has led to a longer transit time between Madagascar and Europe of about (3 to 4) days (figure O).

- Increased amounts of lychees transported in conventional boats requires importers to move towards northern European ports [Vlissingen (Holland), Zeebrugge (Belgium)] which have facilities for receiving, unloading and storing this type of vessel. This option slightly increases transit times.

Given these various elements, to ensure the arrival of Madagascan lychees between the 11th and the 16th of December, it is necessary that the first boat leaves Madagascar between the 21st and the 26th of November.

The analysis of the relationship between the price at the import stage on the French markets and the volumes received after January 1 (figure 7) indicates that: i) the selling price increases when the volume received after January 1 decreases, and ii) once the volumes received exceed 2,000 t, prices fall significantly.

This situation confirms that the commercial position of the Malagasy lychee is now limited to the end of the year festivities in Europe. Sales early in the year are actually only favored by the absence of significant volumes from South Africa and the setting up of much more attractive prices for a connoisseur customer.

Given the lack of new potential markets (the US does not allow the sale of lychee treated with sulfur), it appears that the room for maneuver in terms of developing Malagasy lychee exported volumes is very limited.

\section{Conclusions}

Lychees from Madagascar, although sold for a very short period of time, are currently ranked first in the European markets (close to $19,315 \mathrm{t}$ a year). Unlike other sectors of tropical fruit production, this sector, comprised of a network of small producers $(30,000)$, has become structured by favoring its downstream stages: structures of 


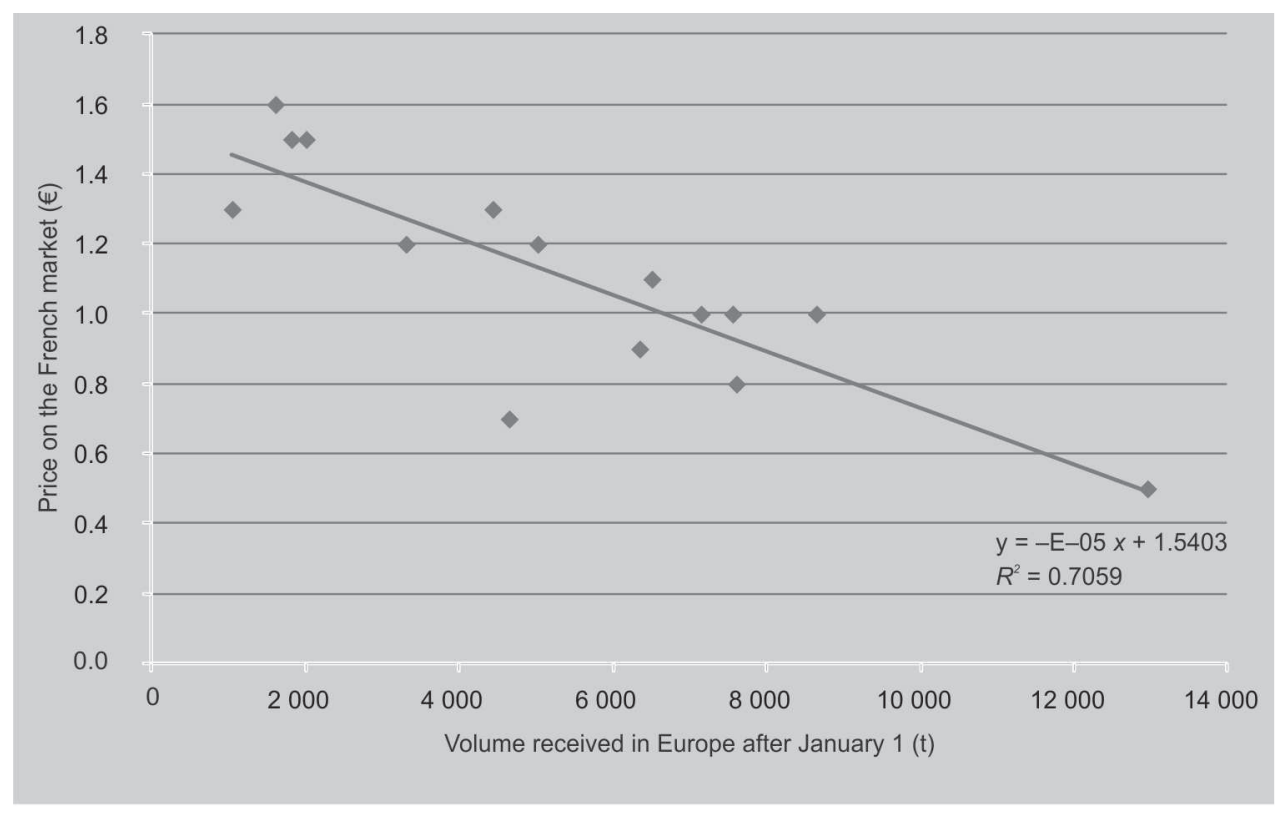

postharvest treatment and packaging, loading and transport logistics, and a niche market.

This structure is linked with: i) the various EU regulations applied to fresh imported products, which require the introduction of technical improvements, controls and compliance with hygiene regulations at the stage of fruit postharvest treatment and packaging at the handling site, ii) the need to put a large volumes of lychees on the European markets before Christmas with a price that guarantees their rapid sales.

However, the targeted markets (mainly Europe), the type of transport used and the positioning of the product in a niche business opportunity related to a specific calendar period (holiday season) require compliance with a particularly strict timetable for harvest as well as for the departure date of the boats. This calendar constraint does not allow considering that this sector is secure because the harvest dates vary annually (we observed differences between the early and late years of up to 3 weeks) as the flowering and fruiting of lychee are mainly under the control of climatic factors [19].

In addition, some factors are not in favor of sustaining the industry in the midterm. These are in particular the absence of interventions (boosting of the production, improving crop management, etc.) upstream of the industry. This lack of mobilization of the farmers in improving the production in order to develop arboriculture does not guarantee compliance with minimum quality criteria and a capitalization on the early character of certain areas or trees.

Consequently, taking into account that sulfur diffusion through the fruit pericarp during the postharvest treatment of the fruit depends on the quality of the fruit at harvest, we can consider that compliance with the sulfur MRL upon arrival in Europe cannot be fully guaranteed [20].

\section{References}

[1] Anon., Dossier du mois : bilan de la campagne litchi 2011-2012 : Madagascar, l'année de la décennie ?, FruiTrop 199 (2012) 12-19.

[2] Houbin Chen, Xuming Huang, Overview of litchi production in the world, with specific in China, in: 4th Int. Symp. Lychee, Longan and other Sapindaceae Fruits, White River, South Africa, 2012, ISHS, Acta Hortic. (in press).

[3] Anon., Dossier du mois : le litchi, FruiTrop 211 (2013) 31-50.

\section{Figure 7.}

Relationship between the lychee volumes from Madagascar received in Europe after January 1 and the price at the import stage on the French market. 
M. Jahiel et al.

[4] Gerbaud P., Le litchi. Fruitrop 178 (2010) 15-38.

[5] Montagnac P., Les cultures fruitières à Madagascar en 1960, Tome 1, Inst. Rech. Agron. Madagascar (IRAM), Tananarive, Madagascar, Doc. 9, 1960, 79-86.

[6] Jahiel M., Madagascar litchi: structuring is needed to ensure sustainability, Fruitrop 50 (1998) 8-10.

[7] Moreuil C., Quelques observations et essais sur le litchi, Fruits 28 (9) (1973) 637-640.

[8] Deullin R., Trupin F., Transport maritime des litchis, Fruits 20 (7) (1965) 341-343.

[9] Trupin F., Bilan de deux campagnes d'exportation de litchis de Madagascar, Fruits 21 (9) (1966) 495-500.

[10] Swarts D.H., Sulphur content of fumigated South African litchi fruit, Subtropica 6 (1985) 18-20.

[11] Kruger F.J., Schoeman M.H., Roets N.J.R., Mhlophe S.D., Postharvest procedures used by the South African litchi export industry, Acta Hortic. (in press)

[12] Jahiel M., Abraham D.., The growth of Malagasy litchi field face to the hardening of European control in the matter of sulphured residue, Acta Hortic. 558 (2001) 63-71.

[13] Loeillet D., The future of the Madagascar litchi industry in question, Fruitrop (15) (1995) 5-6.
[14] Lechaudel M., Damour G., Fournier P., Joas J., Jahiel M., How to predict the harvest date of tropical fruit: from simple methods to complex models, Acta Hortic. 880 (2010) 175-182.

[15] Subervie J., Vagneron I., A drop of water in the Indian Ocean? The impact of GlobalGap certification on lychee farmers in Madagascar, World Dev. 50 (2013) 57-73.

[16] Sivakumar D., Korsten L., Influence of modified atmosphere packaging and postharvest treatments on quality retention of litchi cv. Mauritius, Postharvest Biol. Technol. 41 (2006) 135-142.

[17] GroffW., Some ecological factors in successful lychee culture, Proc. Fla. State Hortic. Soc. 56 (1944) 134-155.

[18] Young T.W., Harkness R.W., Flowering and fruiting behavior of Brewster lychees in Florida, Proc. Fla. State Hortic. Soc. 74 (1961) 358-363.

[19] Costes E., Analyse architecturale et modélisation du litchi, Univ. Sci. Techn. Languedoc, Thèse, Montpellier, France, 1988, 219 p.

[20] Schoeman M.H., Penter M., Kruger F.J., Determination of maturity cut-off points for South African export litchi fruit, ARC-Inst. Trop. Subtrop. Crops, S. Afr. Litchi Grow. Assoc. Yearb. 16 (2004) 14-20.

\section{Experiencia de quince años de campañas de exportación del lichi malgache.}

Resumen - El lichi en los mercados europeos. Con una producción anual mundial de 2,8 Mt, el lichi se clasifica como un fruto menor. La producción mundial se sitúa principalmente en el hemisferio norte (95\%). No obstante, la mayor parte de las cantidades exportadas hacia la UE proviene del hemisferio sur. En este contexto, con sus 100.000 t de producción anual, Madagascar se posiciona como cuarto productor mundial y primer productor en el hemisferio sur. Esta posición se debe al hecho de que los suministros de lichi de la UE son estacionales y se concentran principalmente en el momento de las fiestas de fin de año. Este mercado puede abastecerse en cantidad sólo por los lichis malgaches, dado el inicio de su cosecha en el Océano Índico. La producción del lichi en Madagascar. El cultivo de lichi en Madagascar se remonta a comienzos del siglo XX. Se cultiva principalmente en las bajas tierras tropicales húmedas de la isla y tiene una producción limitada en las zonas de clima subtropical de invierno seco y fresco. Las zonas de producción no se estructuran en vergeles. Consecuentemente, los volúmenes exportados actualmente se basan en una producción alimentada por una multitud de pequeños productores. Se analizaron las características de la exportación del lichi malgache y las consecuencias del contexto de producción en su exportación. Cambios de la legislación europea en referencia a la importación de lichi. Las modificaciones reglamentarias de la UE desde 1987 y los desarrollos comerciales desde 1994 se presentaron a través del análisis de sus efectos en la exportación del lichi malgache Enseñanza de quince años de campañas de exportación del lichi malgache. Los datos acerca de las campañas de exportación malgaches del lichi entre 1996 y 2012 y la evolución de los volúmenes exportados durante esos años ofrecen un profundo análisis de los factores que afectan el sector del lichi malgache. Factores de éxito de la exportación del lichi malgache. Estos factores están relacionados con la seguridad del mercado y las características de una campaña de venta (fecha de la oferta en el mercado europeo, volúmenes exportados y competencia de los productos procedentes de otros países). Conclusión. A pesar de su comercialización durante un periodo muy breve, los lichis de Madagascar ocupan actualmente el primer puesto en los mercados europeos. Gracias al desarrollo de una logística de transporte que emplea cargueros de enorme capacidad han logrado eliminar todo tipo de competencia. Sin embargo este sector se estructura principalmente a posteriori, por lo que se han ignorado las condiciones de su producción, que depende de una red de 30.000 pequeños productores. Esta falta de intervención anticipada de la cadena (refuerzo de la producción, mejora de la gestión de cultivos, etc.) no ayuda a sostener el sector a medio plazo.

Madagascar / Litchi chinensis / datos de producción / estructura de la producción / exportaciones / modos de transporte / reglamentaciones / control de calidad 